\title{
Cegueira e crueldade na narrativa de Tércia Montenegro
}

\author{
Milena Magalhães ${ }^{1}$
}

\begin{abstract}
Isso é desnecessariamente cruel, diz ela com frieza. E desde quando é a crueldade necessária?, pergunta ele. E em que quantidade? Lê os jornais, não fui eu que inventei o mundo.
\end{abstract}

Margaret Atwood, em $O$ assassino cego

\section{Os dons da herança}

No livro de contos organizado por Luiz Ruffato, 25 mulheres que estão fazendo a nova literatura brasileira, publicado em 2004, já é possível averiguar o caráter "perverso" da literatura de Tércia Montenegro. Uma crueldade de contornos inesperados, que impossibilita qualquer redenção. No conto "D.T.", desde as dedicatórias, que estão no início e no meio do conto ("Para José Amorim, violentado e morto na cadeia, em 20 de abril de 2002"; "Para Francilene Amorim, 7 anos, assassinada em 18 de abril de 2002"), a violência dos afetos, da miséria e do vício cria uma ambiência opressiva que nem mesmo os diferentes pontos de vista são capazes de esmaecer. Pelo contrário, a alternância de vozes torna ainda mais brutal o compósito final do conto; uma cena intolerável, que rompe toda medida, instalando o excesso e o horror. ${ }^{2}$

Em seu primeiro romance, Turismo para cegos, de 2015, a escritora cearense, professora na Universidade Federal do Ceará, autora de livros de contos, crônicas e infantis, explora a matéria bruta de outro tipo de violência - e com o mesmo grau de crueldade. Dividida em três partes, compostas de pequenos capítulos, a narração centra-se na história de Laila, que fica gradualmente cega devido a uma doença degenerativa, a

\footnotetext{
${ }^{1}$ Doutora em teoria da literatura e professora da Universidade Federal do Sul da Bahia (UFSB), Itabuna, BA, Brasil. Dorcid.org/0000-0003-3308-6544. E-mail: milenamimo@ gmail.com

2 Jair Ferreira dos Santos assim define crueldade: "Crueldade vem do latim cruor, palavra que significava 'tirar sangue', 'expor a carne crua sob a pele'. Um limite - a pele - é rompido, uma anormalidade é exacerbada, uma dor que foge ao tolerável aparece. Graus na exposição da carne ensanguentada dão a sua medida. Quando sem sangue, metaforizada, a crueldade invade os domínios da alma, dos afetos, da moral, nos quais a violência é também inevitável, ela se exprime quase sempre por formas que juntam a cumplicidade à dissimulação (Dias e Glenadel, 2004, p. 41).
} 
partir do ponto de vista de uma narradora que conta como se estivesse fora da história, mas que participa ativamente do que acontece.

Em uma espécie de compensação, o namorado que ela conhece quando está em processo de perda da visão leva-a para visitar cidades interioranas, como as cidades históricas de Minas Gerais, daí o título. Não se trata de turismo convencional, no qual se colecionam lembranças para depois recordar; é, antes, a constatação das especificidades do estado de cegueira. A materialidade do visível, embora possa ser tocada, é já outra coisa, gera outras percepções: “o viajante volta para casa e suporta a rotina, porque trouxe recordações. Mas Laila não podia guardar uma memória física, prolongar o prazer - o que lembraria de específico? A sensação atmosférica, a pressão da altura enquanto subia pela estrada?" (Montenegro, 2015, p. 77).

Laila é a cega de quem a narradora do romance conta a história. E Pierre, seu namorado. A narradora é a atendente do pet shop onde o casal vai comprar um cão-guia. As razões que justificam a narração da história por essa "observadora", como ela se autodenomina ("uma boa observadora", ressalta), somente se revelam na parte final do livro.

Ao construir uma protagonista, estudante de artes visuais, que se descobre portadora de retinose pigmentar, doença que causa o declínio gradativo da visão, Tércia Montenegro passa a fazer parte de uma linhagem de escritores que perscruta o que há de inquietante em uma perda constitutiva de identidade. Isto é, passa-se do ser vidente a não vidente. É uma outra que surge quando a protagonista Laila passa a não enxergar mais.

Essa outridade agrega a marca da negatividade, daí porque inúmeros sentimentos contraditórios se manifestam: a raiva, o inconformismo, a maldade, a ironia, a dissimulação, por vezes a inércia, a partir de situações que tornam Laila, ao mesmo tempo, vítima e carrasca. Ser cego, ficar cego, ter visão parcialmente limitada, são marcas identitárias que predominam sobre as outras. É como se o cego fosse portador, desde sempre, de um sinal de negatividade, advindo da cena originária que divide o mundo em "antes" e "depois" da luz: "E disse Deus: 'Haja luz!' E houve luz. E viu Deus que era boa a luz, e fez Deus separação entre a luz e as trevas. E Deus chamou à luz Dia, e às trevas chamou Noite" (Gênesis, capítulo 1, versículo 3-5). Essa cena explicita a ideia corrente de que a luz faz parte da misericórdia divina para com os homens; e as trevas, o seu contrário. Portanto, ser portador do que lhe subtrai a visão é inferir no 
homem, de pronto, uma falta. Em Mémoires d'aveugle, Derrida (1990, p. 105, tradução nossa) aponta essa marca sacrificial presente em tantos autorretratos de pintores na história da arte:

[...] sujeito ao desprezo, o cego é também o sujeito do castigo. Uma vez que lhe damos um sentido, o golpe que lhe faz perder a visão inscreve o sacrifício na representação econômica de uma justiça. Fatalidade tão mais implacável quando segue uma lei de retribuição ou de compensação, de intercâmbio e equivalência. A lógica do castigo recobre a da absolvição. A punição pode anular o mal ou até mesmo produzir um benefício (interesse, usura dos olhos perdidos).

A imagem do "sujeito do castigo", punido por uma falta primordial, alheia a sua vontade, tem sido reproduzida sem cessar nas histórias da arte e da literatura. Ligada à ideia de maldição, a cegueira geralmente é posta como uma doença, um mal, que serve para averiguar os limites do visível e, portanto, superá-los ou, ao menos, compensá-los com o aguçamento de outros sentidos. Jorge Luis Borges, como um escritor que vivenciou a experiência da cegueira, escreveu diversos poemas que atestam o sacrifício da perda do "sentido ideal", nas palavras de Derrida, tornando-se testemunha dessa subtração, que relaciona os olhos que não mais veem às lágrimas:

\section{Poema dos dons}

Ninguém rebaixe a lágrima ou rejeite esta declaração da maestria de Deus, que com magnífica ironia deu-me a um só tempo os livros e a noite.

Da cidade de livros tornou donos estes olhos sem luz, que só concedem em ler entre as bibliotecas dos sonhos insensatos parágrafos que cedem (Borges, 1999, p. 207)

No poema, os "olhos sem luz" abrigam a lágrima; leitmotiv da cegueira que ressalta o sofrimento da perda da visão, mas também seu poder revelador. As imagens de humanos banhados em lágrimas correlacionamse quase sempre à ideia de verdade. Uma face que chora é uma face destituída de máscara, que se deixa ser vista para além do ver e do saber. Ao cegar, a lágrima possui o dom de revelar, de efetuar a "lei de compensação", comum ao estatuto dos cegos. Ligada ao discurso bíblico - 
Jesus devolve a visão aos cegos -, tal lei também se associa ao apuro dos sentidos que não o da visão, dando ao cego novas percepções. Em outro poema, Borges não afasta de todo a relação com o dom, a dádiva: "O homem, que está cego, / sabe que já não poderá decifrar / os belos volumes que manuseia / e que não o ajudarão a escrever / o livro que o justificará perante os outros, / mas na tarde que é talvez de ouro / sorri perante o curioso destino / e sente essa felicidade peculiar / das velhas coisas amadas" (Borges, 1999, p. 400). A dimensão do dom que acessa o invisível por outras vias, como o manuseio, para antecipar o que precisa ser pegado ou barrar o que não deve ser tocado, abranda a clausura na qual o cego é confinado. No romance de Montenegro, o manuseio e a expansão dos movimentos do corpo abrem novas perspectivas à personagem cega $\mathrm{e}$ criam outras percepções como artista distintas daquelas de quando enxergava. Do mesmo modo, o corpo no qual um dos órgãos vitais não funciona livra-se mais facilmente - é o que sugere o romance - das representações sociais, permitindo com mais desenvoltura o questionamento dos espaços próprios de segurança, como a família, os amigos, os conhecidos, que apresentam faces deformadas, naquilo que porventura poderia ser visto como propriedades a serem preservadas: a crença e o conformismo da mãe, a paciência e dedicação do namorado. Ao contrário, a dubiedade desses gestos torna evidente tanto a fraqueza quanto o poder inerentes à ideia de sacrifício: "No sacrifício, são um só [vítima e carrasco]: as mãos que apertam misturadas com o pescoço ou com o machado e, pelo menos no instante de uma pintura (uma cena imóvel de morte qualquer), ambos compõem um híbrido, metade fraqueza e metade poder" (Montenegro, 2015, p. 120). Os sinais de impureza das relações, enfatizados por imagens abjetas da arte (a cabeça de Tiradentes na tela de Pedro Américo, a Medusa de Caravaggio etc.), são vividos como um "pesadelo", expressos por uma face de horror incompreensível:

Ela [Laila] assumiu uma expressão de voracidade, os olhos abertíssimos, criando rugas na testa. Seu rosto havia se levantado, e bem à frente seu pai rompeu, num estrondo de pavor: "Que cara é essa, menina? Fique direita!" Laila estremeceu, levou um choque nos nervos. Pierre, o cão, latiu e pôs-se em pé, do lado de fora do vidro (Montenegro, 2015, p. 121).

Cenas como essa corrompem a imagem da face banhada em lágrimas, que se lamenta em silêncio e com certo conformismo. Os espaços identitários, ao contrário, adquirem uma feição disforme, realçando a 
precariedade das relações. A figura da narradora como defensora, juíza, partícipe e testamenteira só não se torna intolerável porque tem a função de desvelar uma espécie de maldade não declarada que se manifesta tanto naquela que perde a visão como em seu entorno.

Este texto, assim, reflete sobre essa estrutura de construção do real ficcional pautada pelo visível e também pelo invisível, uma vez que a narradora não presencia nem participa da maior parte do que conta. A estrutura é o grande trunfo do romance - a aposta na complexificação da posição da narradora que, aparentemente, ao narrar de fora, na verdade, está totalmente implicada naquilo que conta.

A primeira questão a ser problematizada é justamente esta: quem pode falar pelo cego? Sobre aquele que não vê e, no entanto, é visto? Quem tem a autoridade para testemunhar sobre aquele que é, propriamente, a figura da ausência do visível? Não são meras perguntas retóricas se levarmos em conta que, desde o princípio, a narradora confessa que relata, na maior parte do tempo, sobre o que não viu. É Pierre, após ter sido abandonado por Laila, que conta sua história à narradora. Essas informações não são dadas de uma vez, sendo necessário reestruturar os acontecimentos anteriormente narrados à luz dos que são contados mais adiante.

Pode-se afirmar, de antemão, que a crueldade que permeia não apenas a relação do casal, mas a própria personalidade da protagonista não pode ser separada dessas camadas de visão: o atributo da imparcialidade do discurso indireto livre deve ser posto sob suspeição. Usado em boa parte do romance, é um artifício para dar a ideia de neutralidade, a qual é sobrepujada pela narração em primeira pessoa. Nesse sentido, a revelação do final exige, de imediato, uma releitura do romance, pois atesta a parcialidade da narradora, que usurpa o lugar de Laila através de um simulacro de cegueira que se constitui como prova da relação ambígua mantida. No término do romance, torna-se imperativo questionar o ponto de vista que se desprende dos acontecimentos narrados.

Vale lembrar que a autora constrói essa desconfiança em relação ao narrado. $\mathrm{Na}$ análise dos procedimentos narrativos do livro de Montenegro, podemos nos apropriar da expressão de James Wood (2011, p. 20), quando, ao tratar dos tipos de narração, afirma que “[a]té o narrador que não parece confiável costuma ser confiavelmente não confiável". Isto é, na composição do romance, 
espalham-se pistas que permitem visualizar as ambiguidades do que é dito. Wood (2011, p. 21) complementa seu pensamento ao dizer que "o narrador não está sendo confiável porque o autor, numa manobra confiável, nos avisa dessa inconfiabilidade do narrador". É, portanto, uma estratégia discursiva.

\section{A crueldade da narração}

Em Turismo para cegos, identificar o narrador e o jogo de forças que se estabelece a partir de seu ponto de vista é crucial. Em razão de sua perspectiva, a cegueira é vista sem nenhuma compaixão; tanto a piedade como a autopiedade são descartadas. A irreversibilidade da cegueira da personagem é, portanto, uma fatalidade sobre a qual não se cria um histórico de tentativas de reversão. Não há relatos de visitas a médicos, é sumário o anúncio a familiares - em síntese, quase nada relaciona a perda da visão ao sofrimento, à agonia, sendo que o disforme se concentra na personalidade da protagonista. Há algo de sacrílego em suas ações ou - a partir da hipótese aventada aqui - no modo como são narradas. Mesmo que um trecho pudesse conferir alguma empatia, ao expor as limitações da sua condição - por exemplo, "com a cegueira, perde-se o deslumbramento. A capacidade de se maravilhar depende da visão. [...] Laila perdeu a ideia de inteireza e agora sabe do mundo apenas por fatias" (Montenegro, 2015, p. 44) -, este logo é corrompido por outro, com a função de quebrar a "inocência" que porventura pudesse haver. No capítulo intitulado "Não há inocentes", a narradora, em terceira pessoa, conta como Laila, a partir do aguçamento da capacidade de se movimentar no espaço valendo-se de seus outros sentidos, constrói um exercício de imaginação para se confundir propositalmente, dificultando a sua localização no espaço:

A relativa segurança que aprendera, ao se mover contando passadas, ou sentindo a presença de obstáculos silenciosos, era uma espécie de intuição que ela conseguia desligar. Se estava, por exemplo, sentada numa cadeira bem firme, esquecia as diretrizes que a rodeavam, e fazia isso de propósito (Montenegro, 2015, p. 46).

Esse trecho demonstra como a aparente neutralidade conduz, de fato, a um julgamento desfavorável da personagem Laila. Prende-a em uma sucessão de acontecimentos que enfatizam o caráter distanciado e cínico 
em relação à própria condição. Os "exercícios", os "jogos mentais", que poderiam configurar-se como possibilidades de enfrentamento de sua condição, sofrem duras acusações veladas. $\mathrm{O}$ "fazer de propósito" tornase uma marca de maldade impressa. Por meio desses artifícios, consolidase a impressão de que nada nem ninguém escapa aos julgamentos corrosivos da cega; nem as pessoas mais próximas, nem as que encontra ocasionalmente. Também é assim em relação às viagens, aos momentos que vive com Pierre. A agressividade é um excesso que parece inerente à personalidade de Laila, sendo por meio dela que se instala sua indiferença, sua autossuficiência impossível.

Por outro lado, é preciso levar em conta os "pontos cegos", os não ditos, que advêm, como já explicitado, de uma narração fora da experiência contada. $\mathrm{Na}$ divisão das três partes do romance, ora a narradora relata em primeira pessoa, geralmente quando se presentifica para especificar como obteve as informações, ora em terceira pessoa, quando "desaparece" dando lugar à ideia de onisciência. Essa alternância, tão própria da literatura contemporânea, mais que servir para invalidar a "autenticidade" da narração, põe em jogo a questão da sinceridade. A narradora dispõe dos fatos à sua maneira, seleciona não apenas o que conta, mas também o modo como o faz. Como afirma Derrida (2012, p. 73), "o ponto de vista é a perspectiva, isto é, a visão do olhar que, ao pôr em perspectiva, seleciona". Se pensarmos no jogo entre o visto e o não visto, tanto assunto como forma do romance, o descrito pela narradora não deve ser percebido como tal, mas, sim, resultado de uma seleção que contamina tudo; e uma seleção que não é desinteressada. Para Derrida (2012, p. 73), “falar de perspectivismo é dizer que sempre vemos as coisas, que sempre interpretamos as coisas de certo ponto de vista, segundo um interesse, recortando um esquema de visão organizado, hierarquizado, um esquema sempre seletivo que, consequentemente, deve tanto ao enceguecimento quanto à visão". Fazendo uso da matéria do romance, a cegueira não é apenas tema, mas parte do seu modo de construção. A cegueira da artista é também a cegueira imposta, aos leitores, pela narradora que põe em cena os acontecimentos a partir de sua perspectiva.

Ao pensarmos na já clássica divisão feita por Walter Benjamin acerca do narrador e, mais ainda, na leitura de Silviano Santiago a partir da visão do filósofo alemão, a crueldade na qual se sustenta o romance está afim com a seletividade da perspectiva. $\mathrm{Na}$ "primeira hipótese de 
trabalho", Santiago (2002, p. 44) primeiro indaga acerca da noção de autenticidade - "Só é autêntico o que eu narro a partir do que experimento, ou pode ser autêntico o que eu narro e conheço por ter observado?" -, para logo em seguida afirmar:

o narrador pós-moderno é aquele que quer extrair a si da ação narrada, em atitude semelhante à de um repórter ou de um espectador. Ele narra a ação enquanto espetáculo a que assiste (literalmente ou não) da plateia, da arquibancada ou de uma poltrona na sala de estar ou na biblioteca; ele não narra enquanto atuante (Santiago, 2002, p. 45).

Em Turismo para cegos, boa parte do discurso dá a impressão de uma narração imparcial, entretanto a não atuação, a não implicação da narradora é apenas aparente. Esse fingimento serve para escamotear o fascínio - o "pavor", em suas palavras - causado pela figura de Laila. A narradora coloca-se no exterior da ação contada para propagar o malestar, disseminar as diatribes da personagem como fatos incontestáveis; a observação é tudo, menos indiferente ao que ocorre. A narração de fora é apenas um subterfúgio: “[...] mas o fato é que eu costumava ver tanto ele [Pierre] quanto Laila passando pelo quarteirão, e não me cansava de espiá-los. Sabia que moravam perto; numa tarde vira os dois [...]. Graças a essa vigilância, deduzi que um cão-guia seria perfeito para atraí-los à loja" (Montenegro, 2015, p. 165). Ou seja, a narradora trama para fazer parte da história dos dois que, na verdade, trata da história de um trio, no qual ela é a terceira pessoa.

Há aproximação não para o desenvolvimento de uma compreensão do que ocorre com um outro, pois este se configura como adversário, ainda que não o saiba. Laila não participa, efetivamente, do trio. Ela é cega quanto a isso, no sentido literal e metafórico. É vista sem ver. Nenhuma comunidade se estabelece, pois há forças contrárias em jogo. O sentido do autêntico na narrativa é posto em dúvida pelo enquadramento do ponto de vista. A narradora está "cega" ante a totalidade da personagem, vê - ou narra - apenas o que sua visão estabelece como prioritário a ser dito sobre ela, e isso a deforma, retirando toda complacência que sua condição poderia suscitar. Se há razões não espúrias para justificar o comportamento agressivo e retraído de Laila, estas não são jamais enfocadas, pois importa reforçar seu caráter desprezível. O campo do visível, portanto, é contaminado pelo horror invisível da narradora pela personagem. 
Boa parte da literatura contemporânea extrai a sua força da incomunicabilidade entre os viventes. Desse modo, as figuras do sedentário e do viajante, de Benjamin, são insuficientes como representativas da sabedoria que se acumula em uma e outra situação. Na ficção contemporânea, tanto o que fala como o que é falado estão na mesma zona de não pertencimento, daí o gesto narcísico aflorar, em vez do saber, a ponto do aniquilamento do outro: o ato de dizer advém do desejo de tomar posse do lugar do outro. Para desapossar, primeiro, é preciso aniquilar toda e qualquer humanidade. Nesse caso, interdita-se a exemplaridade do narrado. $\mathrm{O}$ movimento é o de espetacularizar os gestos. Em uma época cuja observação pode resultar rapidamente em julgamento implacável da palavra do outro, em que não se distingue mais entre olhar e ser olhado, a exemplo do que se vê nas redes sociais, é ainda mais premente a afirmação de Santiago (2002, p. 59): “O espetáculo torna a ação representação. Dessa forma, ele retira do campo semântico da 'ação' o que existe de experiência, de vivência, para emprestar-lhe o significado exclusivo de imagem, concedendo a essa ação liberta da experiência condição exemplar de um agora tonificante, embora desprovido de palavra". E o fato de essa representação ser ainda mediada pela palavra não invalida a conclusão de Santiago, uma vez que, de tão banalizada, a palavra perdeu seu poder de significação.

O nada a ensinar a que a literatura tem se dedicado é ainda mais intransigente quando pensamos nas formas de desconstrução resultantes daí, que exigem um modo de leitura que tem como ditame a desconfiança em relação ao narrador. Ao comentar sobre seu romance $O$ tribunal da quinta-feira, Michel Laub comenta sobre essa dubiedade do narrador, que, muitas vezes, advém da ignorância, do preconceito ou mesmo da rejeição em relação ao que narra e, no entanto, é parte constitutiva do que intencionava o autor ao construí-lo de determinado modo e não de outro: "Porque o personagem [no caso, trata-se também do narrador] é leigo, ele tem que exagerar em algumas coisas [...]. São necessidades da ficção. Às vezes você tem que ser generalista, direto e errado mesmo, porque é um cara narrando, o discurso é dele, não é meu" (Laub, 2017).

De certa maneira, é o que força o livro de Montenegro. De quem é de fato a voz em frases como: "Ela não era uma heroína, não era exemplar. Não se tornou bondosa por causa da cegueira" (Montenegro, 2015, p. $58)$; "Laila rumina o seu ódio contra esses desconhecidos que recebem o 
que ela não tem" (Montenegro, 2015, p. 62); ou "Laila se inflamava com o caso dos cegos e a sua ilusória 'inclusão'" (Montenegro, 2015, p. 70)? Em Como funciona a ficção, James Wood (2011, p. 21) reflete: "a narração onisciente poucas vezes é tão onisciente quanto parece". Ou ainda: "A chamada onisciência é quase impossível. Na mesma hora em que alguém conta uma história sobre um personagem, a narrativa parece querer se concentrar em volta daquele personagem, parece querer se fundir com ele, assumir seu modo de pensar e de falar" (Wood, 2011, p. 22). Esse desejo de fusão, muitas vezes, impede a distinção entre as vozes, de modo que o narrado tende a passar sem intermediação ao acontecido. Em Turismo para cegos, os trechos em primeira pessoa cumprem a função de pôr em xeque a suposta onisciência da terceira pessoa, obrigando-nos a ver que os acontecimentos são narrados sob o jugo de uma perspectiva.

\section{A cegueira traída}

O aspecto cruel da narração condiz com o afastamento social a que os cegos são submetidos. Todo sinal de aproximação é sentido por Laila como resultado da hipocrisia, da inoperância, do descaso, em relação à cegueira. A lógica mais comum da representação de submissão do cego sofre uma torção. Se, como afirma Derrida (1990, p. 96, tradução nossa), “o cego está, antes de tudo, sujeito a ser desdenhado, o sujeito do desprezo", a reação da portadora de cegueira, excepcionalmente, antecipa-se a esse desprezo. Várias figuras de comparação e a polarização recorrente das personagens (por exemplo, Laila é posta como a carrasca de Pierre que, consequentemente, ocupa o lugar de vítima, mas é também a que sofre os preconceitos inerentes à sua condição) enfatizam essa condição em um duplo papel de ser, ao mesmo tempo, o sujeito desprezível e o que é desprezado.

A violência do ponto de vista também abrange outros personagens. O disforme, inclusive corporal, como as mãos desproporcionais de Pierre, está presente em todas as esferas de suas relações. $\mathrm{O}$ fato de ser um sujeito fraco, desprezível e insignificante surge de um efeito protocolar de percepção. Pierre é o mesmo em qualquer processo descritivo: para Laila, os colegas de trabalho, a família. Sua personalidade não muda porque é tão somente o desdobramento da perspectiva da visão da narradora: "Ele era alguém que eu encontrara 
numa repartição pública e depois aparecera na loja onde eu trabalhava para adquirir um cachorro que ajudasse sua namorada cega - o tipo de gente que se podia ignorar com facilidade" (Montenegro, 2015, p. 147). O desenrolar da narrativa demonstra o quanto essa visão é ambígua e aponta para o caráter problemático da narradora.

Entretanto, a crueldade exposta da narração concentra-se mesmo em Laila. A narradora está o tempo todo próxima a ela, delineando sua face como uma máscara dissimuladora: "Olhava [a instrutora de natação] para Laila como se sondasse sua crueldade, o veneno de que o pai de Mauro lhe acusara, embora o próprio menino não tivesse escutado a frase no piquenique. E Laila bem parecia uma dessas agressivas discretas, que evitam escândalo para subitamente atirar a dolorosa verdade" (Montenegro, 2015, p. 56). A máscara de dissimulação assemelha-se à mortuária, porque os olhos, embora visíveis, são insondáveis, esvaziados pela cegueira. Descreve-se uma violência potencial prestes a explodir, como se por trás dos olhos houvesse uma animalidade apenas contida. É raro, como um segredo, que a máscara de maldade - entrevista pelos outros - se desfaça: "Somente na mais secreta fatia mental de seu temperamento ela se deixava desesperar, elaborando listas de todas as perdas" (Montenegro, 2015, p. 61).

Por outro lado, como já dito, a máscara cruel da personagem funciona como um espelho que mostra as deformações dos outros em relação à pessoa que perde a visão. Um dos aspectos mais perturbadores consiste na mudança de posição imposta pela sociedade, afinal ficar cego é perder não apenas a visão, mas, junto com ela, a própria vida que existia anteriormente. A reação das pessoas mostra-se tão previsível como insuportável. Devido à aversão que se propaga nas relações, o caricatural passa a dominar a cena, no sentido de uma tipificação dos atos, dando ênfase ao que há de pior no aspecto moral. Uma "forma de amesquinhamento" propaga-se:

[...] Laila falava de forma sucinta (e mesmo friamente) sobre a retinose pigmentar. O óbvio seria atormentá-la com perguntas ou protestos, frases de lamúria gaguejantes que ficariam ressoando como refrões. Era isso o que todos haviam feito, começando com cada familiar de Laila e passando pelos amigos, vizinhos ou colegas de universidade. Laila se conformava em ter de consolálos para, num movimento às avessas, sair da postura de vítima, pobre-coitada (Montenegro, 2015, p. 17). 
O modo de sobreviver, então, é assumir a máscara, sem se deixar levar pela queda, retirando a centralidade da deficiência por meio de uma postura altiva, que mantém a devida distância das visões caricatas das quais só é possível defender-se através da desorganização daquilo que se espera dela. A submissão ao outro, a sujeição ao acolhimento como uma prótese da cura, são abortadas: "ninguém poderia dizer que ela tivesse medo de cair, perder o equilíbrio ao andar. Pierre elogiava sua postura elegante, sem bengala que tocasse o chão à frente como um pêndulo. Ela não avançava como os outros deficientes, averiguando o mundo com a boca $e$ olhos abertos, numa expressão vazia" (Montenegro, 2005, p. 35, grifo nosso).

Seu corpo ereto é interpretado como sua diferença dentro da diferença que lhe constitui. Essa postura lhe devolve, em parte, a visão. Os gestos agônicos dos cegos, que tateiam, estendem seus braços em busca de antecipar o que está à frente, é uma diferença difícil de ser suportada, causando reações muito adversas. Expor de maneira tão crua o que é escamoteado, por exemplo, pelo discurso das políticas públicas e das iniciativas de inclusão, não deixa de ser uma das formas que a literatura tem de denunciar o que não está presente em outros discursos em virtude das sanções que os interditam. Enquanto as diretrizes apontam para a inclusão, o texto literário escancara a reclusão, a clausura, evidenciando a $n u d e z$ do cego, exposto ao olhar do outro sem poder retribuir esse olhar, sem poder contar com os modos de interdição que dependem do olhar. E esse é um ponto crucial raramente abordado. Não se trata propriamente de estar de acordo com os ditos, mas de evocar os dizeres que advêm do poder ilimitado da literatura. Ao comentar sobre o início de $A$ nova Justine, Foucault (2016, p. 142) assim evoca esse lugar intransigente: “Logo na primeira linha, Sade explica que, por maior que seja a aversão e o horror que sente em relação a tudo o que vai contar, o homem de letras deve ser filósofo o bastante para dizer a verdade. E mostrará, diz ele, o crime como ele é realmente, vale dizer, triunfante e sublime". Evidentemente, o sublime, aqui, faz par com a abjeção, que "profana" a correção de outros discursos, pondo em dúvida sua intencionalidade manifesta. Um exemplo disso é quando Laila alude com escárnio acerca de um programa de acessibilidade:

Laila se inflamava com o caso dos cegos e a sua ilusória "inclusão". Ouvira falar nos projetos que surgiam como benefícios - simples migalhas hipócritas. Sentira-se afrontada, poucos meses antes, por um programa específico, vindo como 
propaganda pelo correio. Segundo a linguagem metálica da correspondência que Pierre leu, o projeto queria "garantir a possibilidade de fruição da arte para pessoas com deficiências sensoriais, físicas ou intelectuais - por meio de estímulos multissensoriais e lúdicos". "Belo politiquês correto", disse Laila. "Posa de bonzinho, mas revela o juízo por trás dos termos; as palavras não mentem" (Montenegro, 2015, p. 70-71).

Está claro o tipo de substituição. A falta de visão de Laila não é suplementada pela bengala, por nenhum objeto visível; tampouco a audição é primordial. O pensamento implacável e furioso estabelece uma autoimunidade às investidas exteriores que, para ela, não passam de "migalhas hipócritas". Não é a crença que fica patente; é justamente a descrença de qualquer possível acessibilidade, uma vez que esta se relaciona, para ela, ao visível. O inconformismo com a cegueira é também uma revolta contra as pessoas e as instituições com suas políticas públicas: “o que se pretende com 'estímulos multissensoriais e lúdicos'? Multissentidos para pessoas com deficiências sensoriais? Não é cinismo prometer variedade a quem perdeu o básico?" (Montenegro, 2015, p. 71). O básico tem a ver com a perda da função de uma das partes do próprio corpo, que fica, então, incompleto; para fazê-lo funcionar outra vez, é preciso adquirir próteses exteriores ou inerentes a esse corpo. Partes desse corpo de outrora - agora despedaçado pela falta - necessitam revestir-se de próteses ou ser ele mesmo uma prótese. $\mathrm{O}$ discurso maquínico ("funcionar", "prótese" e, portanto, funções das próteses) já demonstra que a dificuldade consiste em substituir a superfície corporal visível pela sensível. A última frase citada continua desta maneira:

Resgata-se a lenga-lenga do estupor de médicos diante da superação de certos pacientes, como nos programas televisivos cheios de oh.. oh... por causa do tal doente que milagrosamente teve o cérebro reconstituído ou soube adaptar partes do corpo para funcionar como outras - assim, feito um engenhoso mecânico que transforma uma bateria velha em algo distinto, um abajur, uma saladeira, qualquer coisa admirável. O amputado aprende a pintar usando os dedos dos pés, o cego se orienta com os ouvidos e pode dançar (Montenegro, 2015, p. 71).

Laila recusa-se, portanto, a reorganizar seu campo corporal, a dar-lhe outros propósitos senão aqueles para os quais originalmente se destina. Dito em outras palavras, que evocam o sentido bíblico, ela se recusa a ser 
"tocada" pelas mãos que poderiam diminuir seu sofrimento pela perda da visão, já que nada teria a mesma plenitude. Diante da impossibilidade de ser tocada pela narrativa do milagre que daria a cura de seus olhos com o toque das mãos, devolvendo-lhe a visão, tampouco aceita a ajuda das máquinas, do "engenhoso mecânico". Impedida de ser curada, ela interdita, sem piedade, a salvação dos outros. Sem aceitar a compaixão, o seu "eu" se reveste de intolerância, que em parte advém da voz narrativa.

Tais intransigências atravessam quase todo o romance. É o aprendizado do butô que rompe com a supremacia da visão e, por fim, retira a sua força primordial. Não à toa, o butô faz Laila "cai[r] dentro do mundo" ou, nas palavras de Bent, o artista que lhe ensina os movimentos, a faz também ser o mundo. Não exatamente a mão supre a falta de visão, mas o corpo todo; um corpo agônico, que expressa todo seu suplício, mas também sua autodeterminação, livre de qualquer convenção rítmica. Uma "dança de loucos", como afirma Pierre, quando se mostra incapaz de compreender os gestos de Laila, traduzidos pela filosofia do butô, que almeja o desvelar dos sentidos e sentimentos, inclusive os mais sórdidos; é um ver a si, sem máscaras. A exterioridade das trevas interiores passa a ser, então, outra forma de ver - monstruosa, como já dito, fora de controle: "Ele [Pierre] não pudera controlar nada: não pudera evitar a vergonha, palavra que ouviu repetida no sussurro das vizinhas. Estava fora de seu alcance qualquer pedido ou ordem para manter Laila nos padrões. Se pudesse, teria instalado comandos em sua mente, para que ela jamais atraísse multidões a vê-la em sua dança grotesca" (Montenegro, 2015, p. 180). O artista é sempre acusado de estar "fora dos padrões", de não obedecer aos ditames da lei e, por isso, sofre as investidas mais cruas. No livro, essa incriminação é uma das tônicas.

\section{Os fins da arte}

Ainda que a narração contra a personagem não permita que tal imagem se distenda, estamos diante da revolta de uma artista. Os gestos de Laila, embora filtrados pela visão a contrapelo da narradora, expressam o desespero de uma artista que perde sua capacidade de trabalho. Procede de narrativas de desgosto próprias do anúncio da cegueira. Nas histórias de cegos e nas histórias feitas por cegos, o lamento é uma das figuras mais recorrentes. Professora de pintura, admiradora de arte clássica, crítica implacável da arte contemporânea - até ela mesma 
experimentar o gesto de perfurar a imagem da pintura clássica com seu corte cego -, a experiência da cegueira é dilacerante e sem intervalo: "'As pessoas pensam que a queda é única', disse Laila. 'Mas eu não parei de ficar cega. Ontem me lembrei dos espelhos, e hoje das fotografias, tudo que vou perdendo" (Montenegro, 2015, p. 77). Espelhos e fotografias são próteses que permitem a duplicação do eu, expõem o olhar narcísico. Apartada de ambos, a sensação é de desaparição.

A luta cega de Laila, portanto, é contra a desaparição; uma luta vã como um dos possíveis finais do romance. Sua dança, na parte final do livro, desloca a imagem da cegueira como doença. Composicionalmente, a visualidade é um traço característico forte do romance. Em um livro sobre a cegueira, no qual a posição do narrador deixa à vista seus pontos cegos, a ênfase nos aspectos visuais é, inegavelmente, uma boa escolha. A trama tecida é metalinguística e aporética, ao estabelecer a presença do visível no espaço da invisibilidade. Por assim dizer, é uma disposição monstruosa. De fato, as descrições remetem à monstruosidade, instalam a incerteza e, por fim, configuram Laila como uma ameaça, criando, a partir daí, a parte mais significativa do romance:

Pierre agora não pode contemplar uma praia sem que se lembre da dança. Parece que a todo instante verá, contra as leves ondulações azuis, uma silhueta esvoaçante e contorcida. Laila se transformava em monstro pálido [...]. Latejava, quebradiça e lentamente selvagem, experimentando desarticulações, como um fantoche se equilibrando na pista de uma caixinha de música. [...] Uma figurinha monstruosa e calma (Montenegro, 2015, p. 175).

Nas duas partes anteriores do romance, algumas situações se repetem, com as sucessivas viagens que, a cada vez, produzem malestar generalizado, aumento da insatisfação. Já na terceira parte configura-se o incalculável, evidenciando que o "monstro", a "figurinha monstruosa e calma", engendra reações impensadas, que ameaçam a racionalidade dos envolvidos. É quando a narradora confessa sua obsessão: “Àquela altura, eu estava obcecada pela vida dos dois. O que iniciou como uma espionagem ociosa, feita pela janela do pet shop, dominou meu pensamento - sobretudo em torno de Laila, sua figura incompreensível e poderosa" (Montenegro, 2015, p. 190).

Essa obsessão - dramática, cruel, feroz - por Laila a distingue dos outros sujeitos, configurando um pensamento sobre o ser artista. Vidente, ela destila toda sorte de preconceitos contra a arte contemporânea; há uma 
reverência à arte clássica que a leva a contrapor-se a qualquer outra manifestação artística. Novamente, é a questão do tratamento dado às imagens do passado e do presente. A deferência pelo permanente das obras do passado em detrimento à transitoriedade das do presente reforça o apego ao visível; no fundo, a defesa da arte clássica é uma defesa do imutável. A memória relaciona-se ao visível, no sentido clássico de representação, que possui um valor já historiado: “No íntimo, Laila começava a se despedir das suas telas e desenhos - embora o que mais lhe doesse fosse a iminência de esquecer uma obra de Vermeer, Rembrandt ou Velásquez. Nenhum aluno tinha condições de sondar aquele sofrimento, e ela não tentou dividi-lo com ninguém" (Montenegro, 2015, p. 18).

A aura da obra de arte está ligada à ideia de um visível original, obtido por meio de uma experiência única que não poderia ser copiada, ou melhor, banalizada pela reprodução das imagens. $O$ trabalho de duplicação ficaria a cargo, para Benjamin, da memória involuntária que expandiria as narrativas desse acontecimento único. $\mathrm{O}$ medo do esquecimento é, portanto, o temor de não conseguir produzir memória fora do espaço do visível. Somente quando está totalmente cega, a visão apocalíptica, diante da imagem, que a conduz à ideia de fim, é perfurada justamente para desapropriar a aura. Para criar outra experiência com a obra de arte, é preciso renunciar ao suporte estável do visível e lançar-se com crueldade contra ele:

[...] Laila fazia colagens; há dias experimentava um novo tipo de arte, ou ao menos uma distração. Mandava reproduzir pinturas de naturezas-mortas, sobretudo flores. Sempre obras famosas: Monet, Rembrandt, Van Gogh - em reproduções da melhor qualidade. Pierre buscava o material na fotocopiadora, assegurando-se das cores fiéis, que comparava com o modelo de livros e catálogos. Trazia para casa cópias do tamanho de pôsteres, e tinha até pena de ver como Laila se punha a destroçálas, recortando aleatoriamente pedaços do centro dos quadros (Montenegro, 2015, p. 41).

A cegueira cria a obra, porém não mais baseada nos preceitos de antes. Tendo visível apenas a memória do rastro das "obras famosas", tampouco a cópia se sobressai, mas, sim, o que é feito a partir dessas cópias destroçadas, conformando o que, segundo Derrida (1990, p. 72, tradução nossa), já está em sua origem: “A ruína não ocorre como um acidente em um monumento antes intacto. No 
começo, há a ruína. Ruína é o que acontece com a imagem desde o primeiro olhar". Como artista, Laila ataca a integridade da obra sem desintegrá-la. Em certo sentido, seu trabalho, que será exposto e, mais tarde, destruído, conta sua história. A memória não permanece intacta, porque nenhuma resta; é sempre o atrito do passado com o presente que põe à prova a visibilidade, contaminada desde o início pela invisibilidade. $\mathrm{O}$ modo como se lida com isso determina o tamanho das "rasgaduras":

Ao final, restavam no chão peças angulosas de papel, fragmentos de rosas e vasos, nenhum desenho com todos os seus limites. Havia uma ruptura em meio a qualquer pétala, ou um corte repentino na extremidade de uma folha, mas apesar disso a figura ainda era reconhecível. O trabalho de recorte parecia tosco, entretanto a combinação que depois surgia estranhamente se impregnava de harmonia (Montenegro, 2015, p. 41).

Impossível não pensar no sentido de "rasgadura" prefigurado por DidiHuberman (2013, p. 186), ao discutir os modos de ver a história da arte e sugerir que "ver", "olhar" consiste em perder "a unidade de um mundo fechado para se encontrar na abertura desconfortável de um universo agora flutuante, entregue a todos os ventos de sentidos". A "ruptura", o "recorte", o "corte repentino" efetivados pela protagonista em imagens de obras antes intocáveis são o anúncio das aberturas violentas de sentido proporcionadas pela cegueira que, como demonstrado, modifica todas as suas formas de vida, vista através da crueza da narradora e, consequentemente, da linguagem do romance, que é também uma história de fascínio, com tudo o que se pode produzir a partir daí: inveja, despeito, incompreensão; paixão, enfim. O fascínio arruína o ponto de vista da narradora, que nos entrega os rastros do seu deslumbre, ofertando-nos, por conseguinte, um recorte contraditório e espantoso.

\section{Referências}

BENJAMIN, Walter. Obras escolhidas: Magia e técnica, arte e política - Ensaios sobre literatura e história da cultura. Tradução de Sérgio Paulo Rouanet. São Paulo: Brasiliense, 2012. v. 1.

BORGES, Jorge Luis. Obras completas de Jorge Luis Borges. São Paulo: Globo, 1999. v. 2 
DERRIDA, Jacques. Mémoires d'aveugles: l'autoportrait et autres ruines. Paris: Réunion des Musées Nationaux, 1990.

DERRIDA, Jacques. Pensar em não ver: escritos sobre as artes do visível (19792004). Tradução de Marcelo Jacques de Moraes. Florianópolis: Editora da UFSC, 2012.

DIAS, Ângela Maria; GLENADEL, Paula (Org.). Estéticas da crueldade. Rio de Janeiro: Atlântica, 2004.

DIDI-HUBERMAN, Georges. Diante da imagem: questão colocada aos fins de uma história da arte. Tradução de Paulo Neves. São Paulo: 34, 2013.

FOUCAULT, Michel. A grande estrangeira: sobre literatura. Tradução de Fernando Scheibe. Belo Horizonte: Autêntica, 2016.

GÊNESIS. In: Bíblia de Estudo Pentecostal. Tradução de J. F. de Almeida. São Paulo: CPAD, 2007.

LAUB, Michel (2017). Está aberta a sessão: entrevista concedida a Daniel de Mesquita Benevides. Cultura! Brasileiros, São Paulo, fev.

MONTENEGRO, Tércia. Turismo para cegos. São Paulo: Companhia das Letras, 2015.

RUFFATO, Luiz. 25 mulheres que estão fazendo a nova literatura brasileira. Rio de Janeiro: Record, 2004.

SANTIAGO, Silviano. O narrador pós-moderno. In: SANTIAGO, Silviano. Nas malhas da letra. Rio de Janeiro: Rocco, 2002.

SCHITTINE, Denise. Ler e escrever no escuro: a literatura através da cegueira. Rio de Janeiro: Paz \& Terra, 2016.

WOOD, James. Como funciona a ficção. Tradução de Denise Bottman. São Paulo: Cosac Naify, 2011.

Recebido em 26 de junho de 2017.

Aprovado em 8 de janeiro de 2018.

\section{resumo/abstract/resumen}

\section{Cegueira e crueldade na narrativa de Tércia Montenegro}

Milena Magalhães

Este texto aborda o romance de estreia da escritora cearense Tércia Montenegro, Turismo para cegos, que traça um retrato perverso da condição da cegueira. Parto 
do pressuposto de que não se compreende a crueldade que abrange a totalidade dos afetos nas relações engendradas no livro sem levar em conta os "pontos cegos" da história, que resultam de uma narração fora da experiência primordial da perda da visão. Assim, levando-se em consideração que a perspectiva seleciona o narrado, o que é descrito não deve ser percebido como tal, adquirindo o status de verdade, mas, sim, resultado de uma seleção que contamina tudo o que é dito. Uma vez que a história é ambientada no terreno das artes visuais, estão em jogo os limites entre o visível e o invisível. Para analisar esse conjunto de situações, mantenho-me próxima da letra do romance e do vocabulário de Jacques Derrida quando trata sobre as artes do visível.

Palavras-chave: Tércia Montenegro, literatura brasileira contemporânea, cegueira, crueldade.

\section{Blindness and cruelty in the narrative of Tércia Montenegro}

\section{Milena Magalhães}

This text approaches the debut novel of Cearense writer Tércia Montenegro's, Turismo para cegos, which creates a perverse portrait of the condition of blindness. I propose that the cruelty that pervades all of the feelings in the relationships that the book portrays cannot be understood without taking into account the story's "blind spots". These blind spots are the consequence of a narration that happens outside of the primordial experience of the loss of the sight. Therefore, taking into account that the perspective determines what is narrated, what is described is not to be perceived as such, acquiring the status of truth, but rather as the result of a selection that contaminates everything that is said. Since the story is set in the field of the visual arts, what is at stake are the boundaries between the visible and the invisible. To analyze this set of situations, I closely follow the letter of the novel and Jacques Derrida's vocabulary regarding the arts of the visible.

Keywords: Tércia Montenegro, contemporary Brazilian literature, blindness, cruelty.

\section{Ceguera y crueldad en la narrativa de Tércia Montenegro}

Milena Magalhães

Este texto aborda la ópera prima de la escritora Cearense Tercia Montenegro, Turismo para ciegos, que traza un retrato perverso de la condición de la ceguera. Parto del supuesto de que no se puede comprender la crueldad que abarca la totalidad de los afectos en las relaciones engendradas en el libro sin tener en cuenta los "puntos ciegos" de la historia que resultan de una narración fuera de la experiencia primordial de la pérdida de la visión. Así, teniendo en cuenta que la perspectiva selecciona lo narrado, lo que se describe no debe ser percibido 
como tal, adquiriendo el status de verdad, sino el resultado de una selección que contamina todo lo que se dice. Ya que la historia está ambientada en el terreno de las artes visuales, están en juego los límites entre lo visible y lo invisible. Para analizar este conjunto de situaciones, me valgo del texto de la novela y del vocabulario de Jacques Derrida cuando trata sobre las artes de lo visible.

Palabras clave: Tércia Montenegro, literatura brasileña contemporánea, ceguera, crueldad. 